\title{
CONSERVAÇÃO DA NATUREZA E MODULAÇÃO DO ESPAÇO: ANÁLISE DAS UNIDADES DE CONSERVAÇÃO DO MOSAICO SERTÃO VEREDAS PERUAÇU
}

\section{CONSERVATION OF NATURE AND MODULATION OF SPACE: ANALYSIS OF THE CONSERVATION UNITS OF MOSAIC SERTÃO VEREDAS PERUAÇU}

\author{
Geraldo Inácio Martins ${ }^{1}$ \\ João Cleps Junior ${ }^{2}$
}

\begin{abstract}
RESUMO
Os objetivos e as estratégias subjacentes à criação e à implementação de Unidades de Conservação são múltiplos e envolvem, por exemplo, questões estritamente técnicas, como a preservação de uma espécie, e questões mais amplas como conservar parte de um bioma ou paisagem. Ao analisar a historicidade das Unidades de Conservação do Mosaico Sertão Veredas Peruaçu, Norte de Minas Gerais e Sul da Bahia, a intenção deste texto é mostrar outra faceta deste processo: a face iminentemente política e territorial da conservação da natureza. Trata-se de pensar as múltiplas determinações deste processo, e mais, responder à seguinte questão: quais elementos deram condições, ou mesmo determinaram, a criação das UCs que formam o MSVP? Com base na análise de fontes documentais e de documentos técnicos, foi possível compreender as premissas subjacentes à demarcação das UCs, seus aspectos políticos e, sobretudo, destacar a lógica territorial cujas tessituras estão subjacentes aos conflitos, interesses e estratégias de controle do uso da natureza e sua diversidade biológica.
\end{abstract}

Palavras-chave: Unidades de Conservação. Natureza. Políticas ambientais. Modulação do espaço.

\section{ABSTRACT}

The objectives and strategies underlying the creation and implementation of Conservation Units are multiple and involve, for example, strictly technical issues such as the preservation of a species, and broader issues such as conserving part of a biome or landscape. In analyzing the historicity from the Conservation Units of Mosaic Sertão Veredas Peruaçu, northern Minas Gerais and Southern Bahia, the intention of this paper is to show another facet of this process: the imminently political and territorial face of nature conservation. It is a matter of thinking about the multiple determinations of this process, and more, to answer the following question: what elements have given conditions or even determined the creation of the UCs that form the MSVP? Based on the analysis of documentary sources and technical documents, it is possible to understand the premises underlying the demarcation of PAs, their

\footnotetext{
${ }^{1}$ Professor Adjunto da Universidade Federal de Alagoas. E-mail: geraldo.martins@penedo.ufal.br

${ }^{2}$ Professor Adjunto do Programa de Pós- Graduação em Geografia, Universidade Federal de Uberlândia. E-mail: jclpes@ufu.br

Estudos Geográficos, Rio Claro, 15(1): 184-209, jan/jun. 2017 (ISSN 1678-698X)

http://www.periodicos.rc.biblioteca.unesp.br/index.php/estgeo
} 
political aspects and, above all, to highlight the territorial logic with the underlying conflicts, interests and strategies of the use control of nature and your biological diversity.

Keywords: Conservation Units. Nature. Environmental policies. Modulation of space.

\section{INTRODUÇÃO}

A conservação da natureza por meio da criação de espaços protegidos que, no Brasil, compreende as Unidades de Conservação - UCs e as suas diversas categorias, tem uma historicidade complexa. É pensando nesta historicidade que discutimos a criação das UCs da região Norte de Minas Gerais e Sul da Bahia que compõem o Mosaico Sertão Veredas Peruaçu - MSVP, seus objetivos e estratégias. Trata-se de pensar as múltiplas determinações deste processo, e mais, responder à seguinte questão: quais elementos deram condições ou mesmo determinaram a criação das UCs que formam o MSVP? Ao responder esta questão, dois fatores são evidenciados: primeiro, a conservação é uma estratégia política e, como tal, tem como objetivo o controle e a interdição de uso dos fundos territoriais. A segunda questão revela as contradições do Estado no controle destes fundos territoriais que submete o mesmo espaço a duas lógicas distintas de uso - através de projetos econômicos de desenvolvimento (incentivando o uso) e por meio de políticas ambientais, incentivando o controle e interdições de uso por meio das UCs.

A primeira UC de proteção integral criada na região Norte de Minas Gerais foi - Parque Nacional Grande Sertão-Veredas - PARNA GSV no final da década de 1980. A década de 1990 foi mais profícua devido ao fato de o número de UCs ter aumentado substancialmente. Surgiram novas áreas protegidas com outras categorias de manejo como, por exemplo, as Áreas de Proteção Permanente APAS, as Reservas Particulares do Patrimônio Natural - RPPNS e as Reservas de Desenvolvimento Sustentável - RDS. Ao iniciar os anos 2000, o Norte de Minas tem uma nova característica territorial - a região da conservação da natureza devido à expansão em escala das áreas de proteção ambiental.

Ao refletirmos sobre a história de composição das UCs pertencentes ao MSVP, estamos também refletindo sobre a geografia histórica das políticas de conservação da natureza e como estas se materializam sobre a região Norte de Minas. A partir disso, criam-se os instrumentos para se refletir a natureza das próprias UCs e suas estratégias. Esperamos, ao final do texto, demonstrar como este processo desencadeou novas formas espaciais com conteúdos, formas, normas e objetivos distintos. Objetivamos que este texto nos forneça instrumentos para analisar a formação de uma biorregião, cujo pilar principal é a conservação da natureza e os sistemas de coesão por ela criados.

Metodologicamente, este texto foi elaborado a partir da análise de fontes técnicas - Planos de Manejo, Planos de Desenvolvimento, etc. A análise destas fontes demonstrou os quatro eixos da criação e gestão das UCs no Norte de Minas: primeiramente, o sentido eminente de "risco" aos diferentes elementos naturais devido aos usos espoliantes; tais usos de riscos são variados, desde as queimadas e carvoejamento, até os projetos agropecuários e monoculturas, e em alguns casos, a solta de gado de comunidades camponesas. Aliado a este processo, há uma "espécie" de naturalização da região, isto é, a identificação da região mais pelas características naturais do que pelos fatores históricos. O terceiro eixo refere-se às

Estudos Geográficos, Rio Claro, 15(1): 184-209, jan/jun. 2017 (ISSN 1678-698X)

http://www.periodicos.rc.biblioteca.unesp.br/index.php/estgeo 
políticas de compensação ambiental e a conservação em reservas particulares. $E$ mais recentemente, a relação entre a "manutenção" dos elementos da cultura regional e a conservação da natureza por meio das UCs de uso sustentável.

Para dar conteúdo a este quadro interpretativo delineado, dividimos este texto em três itens, além desta introdução e das considerações finais. O primeiro trata da relação entre projetos de desenvolvimento e a criação de UCs de proteção integral no Norte de Minas, sobretudo, destaca os mecanismos de compensação ambiental. O segundo item reflete sobre a relação entre o público e o privado e os interesses na materialização da conservação ambiental e no controle dos fundos territoriais entre as UCs do MSVP. E, por fim, é preciso esclarecer que, apesar do número relevante de UCs de uso sustentável (as APAs e uma RDS), estas ficaram fora do quadro aqui em análise.

\section{POLÍTICAS AMBIENTAIS E UNIDADES DE CONSERVAÇÃO NO NORTE DE MINAS GERAIS}

A proposta deste item é refletir o quadro no qual se inserem as políticas ambientais de conservação da natureza por meio das UCs na região Norte de Minas Gerais. Antes de esclarecer este processo, foi necessário compreender as características e os processos que abriram espaço para inserção de tais políticas ambientais na região. Conforme veremos, a conservação da natureza atua como mecanismo de mediação ou até mesmo de "antítese" à expansão dos usos predatórios, geralmente incentivados por políticas de Estado. Este quadro se empiriciza no Norte de Minas Gerais a partir da década de 1970, por meio dos projetos de desenvolvimento.

Nesse sentido, a primeira atividade foi entender os motivos políticos, sociais, econômicos, etc., que nos ajudassem a compreender a criação de mais de 20 UCs em pouco menos de duas décadas em todo o Norte de Minas Gerais. Cada decreto ou portaria estudado havia sempre a descrição da riqueza biológica e da importância dos recursos hídricos, etc. No que se refere às justificavas, sempre giravam em torno dos altos índices de degradação sofridos por estes ambientes, as belezas cênicas e a importância ecológica. Até este momento, a criação de UCs no Norte de Minas Gerais não demonstrava especificidade em relação às demais regiões do Brasil como todo. Isto é, sempre que há conflito entre o uso espoliativo da natureza e a necessidade de conter este uso devido às pressões de ambientalistas e da sociedade em geral, o Estado cria uma UC.

À medida que avançamos nas análises, um ponto específico nos chamou a atenção - a supervalorização da natureza Norte mineira ou a sua positivação. Contrariamente aos eventos históricos, no qual a natureza (a falta de chuvas, o clima, o solo etc.) era o principal mecanismo pelo qual se representava negativamente a região, isto é, o "atraso" econômico da região deve-se às questões naturais (naturalização das relações sociais), na criação das UCs, estes mesmos elementos mudam de status. A natureza sai do plano negativo e entra enquanto elemento de valorização da diversidade biológica e cultural da região, e como tais, devem ser valorizados e preservados.

Até aproximadamente a década de 1970, a natureza da região Norte de Minas foi tratada em seu aspecto negativo. Fazia-se a correlação entre os problemas econômicos e as condições naturais. Isto se materializa em vários textos clássicos - Donald Pierson e Yves Gervaise, por exemplo- todos retratando a 
"guerra" do homem para romper as adversidades desta natureza no intuito de desenvolvê-la. Gervaise (1975), ao se referir aos Cerrados Norte mineiros como domínios de "vasta solidão, entrecortada, de raro em raro, por riachos magros e temporários, repete (...) essa impressão de seca e solidão", é um exemplo desta construção discursiva com base na negatividade (GERVAISE, 1975, p. 21 [grifos nossos]).

Seguindo as análises deste autor, este tratamento negativo ganha mais concretude. Ao se referir a Januária, local no qual o "contato com a zona de Caatinga introduz mais um elemento de variedade (...)" e aos Cerrados que "mesmo nas condições mais favoráveis, (...) não justificam a instalação do povoamento denso. Domínio adaptado à criação, ele é, pela pobreza dos solos que se renovam lentamente, bastante hostil à agricultura que se refugia ao longo dos vales" (GERVAISE, 1975, p. 34-35-36. [Grifos nossos]). A ideia de "solos pobres", de vegetação "má" é uma das representações historicamente construída, mas isto tem efeitos perversos, sobretudo, na esfera do planejamento e das políticas públicas.

Gervaise argumenta que o "Norte não é a única região atrasada de Minas (...) mas esta paisagem de "miséria" é o resultado "do complexo isolamento, e de condições naturais mais ásperas" (GERVAISE, 1975, p. 21 [Grifos nossos]). Esta face negativa atribuída à natureza regional foi embutida nas políticas de desenvolvimento impostas à região a partir da década de 1970. Para desenvolver o quadro de pobreza gerado por uma natureza "injusta", é preciso rompê-la, revolver o seu solo "pobre", derrubar a sua vegetação "feia" e no lugar deve arvorecer o moderno. Modificar suas características por meio do incremento de técnicas "modernas" - produtos químicos, os correntões e a drenagem das veredas. Ao incorporar esta negatividade da natureza aos projetos de desenvolvimento, levou-se aquilo que Carlos Eduardo Mazzeto Silva (2009) denominou "modernização predatória" do Cerrado.

Esta narrativa pelo viés depreciativo faz parte de um conjunto enunciativo cujo objetivo é justificar determinadas ações sobre o espaço, isto é, procede a uma modalidade discursiva para viabilizar uma legitimidade ideológica sobre a natureza e sobre o espaço que a acolhe. Em outras palavras, conforme Silva (2009, p. 64) "é como se a natureza e as populações locais, espalhadas pelos Gerais até aquele momento, não tivesse nenhum significado, nenhuma riqueza cultural e ecológica". A ideia de "vazio" representa bem este processo, espaço no qual "nada" há, as ações de desenvolvimento não podem ser positivas. Nesse sentido, a negatividade da natureza se estende aos homens que habitam tal lugar.

Nota-se, com este discurso, uma relação de exterioridade à natureza, ou melhor, ao Cerrado que é, ao mesmo tempo, um "empecilho" ao desenvolvimento, mas com as técnicas modernas torna-se um "recurso". Este é o paradoxo desta modalidade discursiva, esta transposição de um elemento negativo, quando ocupado tecnicamente, torna-se positivo. Aqui, é preciso algumas ponderações. Quando ocupado pela lógica de desenvolvimento, o Cerrado, o Norte de Minas, não é mais o mesmo, sua natureza mudou, é um outro Cerrado, é outro Norte de Minas. Nesse sentido, a positividade não é sobre o conjunto primeiro, mas a sua transformação em segundo conjunto de "coisas". Coisas porque este processo se faz pela coisificação da natureza e dos homens.

Este processo foi guiado por uma série de instituições, como a Superintendência de Desenvolvimento do Nordeste - SUDENE, criada em 1959 que ofereceu incentivos à industrialização e ao desenvolvimento de projetos 
agropecuários; a Fundação Rural Mineira de Colonização e Desenvolvimento Agrário - RURALMINAS, que concedeu terras públicas para as monoculturas de eucalipto e para os projetos de assentamento e colonização. Nesse sentido, a primeira questão a se considerar é que o Estado foi o principal agente fomentador desta modernização capitalista, garantindo condições para o funcionamento das estruturas produtivas recém-instaladas.

Conforme Luciene Rodrigues (2000), é preciso considerar as ações do Estado na região Norte de Minas em quatro grandes eixos: "(a) grandes projetos agropecuários; (b) industrialização; (c) reflorestamento; (d) projetos de irrigação" (RODRIGUES, 2000, p. 124). No que se refere às áreas rurais, propriamente, estas ações deram-se no sentido de transformar a base técnica da agricultura, transformando áreas até então destinadas à produção camponesa em espaços de produção capitalista da agricultura, criando grandes projetos como meio principal para atingir tal objetivo. Um exemplo que nos é pertinente, neste artigo, é o Projeto Jaíba, gestado neste cenário de acirramento das relações produtivas, ajustamentos e transformações das dinâmicas do espaço regional Norte mineiro.

Em sentido complementar, podemos situar as políticas de reflorestamento desenvolvidas no entorno do Distrito de Serra das Araras (Chapada Gaúcha), nas bacias do rio Pandeiros, Cochá e Gibão (Januária). Desde a década de 1970, a região Norte de Minas como um todo foi palco da materialização de plantios extensivos de eucalipto e pinus. Aqui, mais uma vez, destaca-se a presença do Estado, como financiador deste processo. Conforme Maria Bárbara M. Bethonico (2009, p. 204), "os plantios de eucalipto, (...) foram valorizados no contexto histórico de sua implantação, como representantes vivos do progresso e de possibilidades de melhoria das condições de vida".

Junto aos monocultivos de eucalipto e pinus veio a ideia de "progresso", a ideia de participar de algo maior "em um projeto de nação", justamente pela negação daqueles elementos de estruturação da região - as comunidades camponesas, o Cerrado, etc. O Cerrado em troca do desenvolvimento, a natureza bio-diversa em troca da homogeneidade da paisagem. No entanto, "[...] a prometida chegada do progresso com os plantios de eucalipto dentro dessa lógica capitalista gerou mais desigualdade entre as regiões mineiras e uma maior relação de mando sobre as comunidades rurais" (BETHONICO, 2009, p. 204).

Os impactos ambientais do reflorestamento são diversos. O primeiro deles é a retirada das matas nativas que acarreta perda do solo, assoreamento dos rios, perda de diversidade genética, etc. Conforme Baggio Filho (2003), os efeitos ambientais negativos começam com o aumento de consumo de água pelas novas espécies inseridas no ambiente, eucalipto e pinus, e passa pela "ciclagem de nutrientes, propriedades do solo, efeitos alelopáticos, consumo de fertilizantes e agrotóxicos", e termina, no primeiro corte das árvores, com a erosão dos córregos e rios e secagem das veredas, fuga e/ou morte de animais (BAGGIO FILHO, 2003, p. 54).

Enfim, a negativação da natureza e da região têm efeitos perversos tanto no que se refere à natureza, quanto aos homens que estes lugares habitam. Estes elementos de "modernização" implicados no discurso e na prática levam aos ditos problemas ambientais regionais decorrentes da "gestão do território", ou melhor, "do modo de apropriação e uso do território e dos seus recursos" (BECKER, 1992, p. 128). A partir desta análise, fica em evidência que os modelos de desenvolvimento pensados em uma lógica estritamente funcional e economicista, como aqueles impostos a região na qual situa o MSVP, é o elemento chave para entender a crise ambiental imposta nos mais diversos lugares que compõem o Norte de Minas -

Estudos Geográficos, Rio Claro, 15(1): 184-209, jan/jun. 2017 (ISSN 1678—698X)

http://www.periodicos.rc.biblioteca.unesp.br/index.php/estgeo 
escassez de água, assoreamento de rios, etc. Estes modelos de desenvolvimento são expressão concreta de um tipo de "estrutura social", um modo político de se pensar a apropriação "da coisa pública".

Nesse sentido, o arcabouço discursivo negativando os aspectos naturais da região, as políticas de desenvolvimento e os problemas ambientais são indissociáveis. O discurso garante a efetividade ideológica das ações que, por meio dos projetos de desenvolvimento, produzem novos ordenamentos espaciais. Estes novos ordenamentos, porém, pela sua lógica funcional e espoliativa, colocam em "risco" a biodiversidade regional. O discurso constrói a carga ideológica e produz consensos, as ações do Estado atendem interesses e interessados, a natureza torna mote discursivo de um e de outro. Estabelece-se a tríade natureza - discurso interesses: ação do Estado.

A partir do final da década de 1980 e início da década de 1990, com fins dos créditos para o setor de reflorestamento e escassez de créditos para os projetos de desenvolvimento, outro corpo discursivo ganha materialidade - a valorização da natureza enquanto elemento da região Norte de Minas. O discurso da negatividade começa a ser redimensionado (não em totalidade) diante dos impactos ambientais e sociais dos projetos de irrigação, povoamento e de reflorestamento. Iniciamos, portanto, uma terceira fase de construção discursiva a respeito da natureza, a sua positivação. E deste movimento surge a proposta de proteção, preservação e conservação da natureza, e surge também as primeiras UCs. O que é este discurso de positivação da natureza? Trata-se de um duplo movimento.

De um lado, a presença de ambientalistas, cientistas e críticos dos projetos de desenvolvimento abrem espaço para diálogos e críticas a estes modelos impostos. De outro lado, a própria legislação ambiental brasileira e, sobretudo a mineira, passam a reconhecer a importância da biodiversidade devido aos tratados internacionais de proteção e conservação da natureza. O Estado de Minas Gerais aprova Leis importantes neste sentido, por exemplo, a Lei no 9.375, de 12 de dezembro de 1986 que torna os sistemas de veredas de preservação permanente de interesse comum (GOVERNO DE MINAS GERAIS, 1986).

Evidentemente que este processo é mais amplo, mas o amadurecimento da legislação e das políticas ambientais contribui muito neste processo. Este processo de positivação aparece claramente entre cientistas de várias formações quando discutem a região, e também aparece nos atos de criação de UCs e nos planos de manejo. Nesse sentido, a positividade da natureza refere-se a um conjunto de elementos que lhe confere valor em si, isto é, a natureza é valorizada pelos seus atributos. Neste processo, não se demanda técnicas de intervenção para melhorá-la, ao contrário, enquanto totalidade, nenhum elemento da natureza é redutível a outro e o conjunto revela a longa história de co-evolução.

Este movimento de positivação passa, em graus distintos, por vários setores da sociedade e revela as intenções, interesses e interessados. Este enlace discursivo de valorização coloca em cena os sujeitos sociais. No lugar dos grandes empresários surgem as ONGs ambientalistas (nacionais e internacionais). No lugar de derrubar o Cerrado para monocultivos, demarca-se áreas para conservá-lo. No lugar de políticas de créditos, demanda-se Plano de Manejo e a efetiva conservação dos ambientes protegidos. Esta mudança discursiva não é suficiente para conter a expansão dos processos degradativos e a constituição de espaços protegidos é o caminho indicado para conter a degradação. Mas só se pensa em conservar porque, atualmente, a natureza merece ser conservada pelos seus atributos. É interessante notar este movimento, a conservação colocada diante das práticas espoliativas Estudos Geográficos, Rio Claro, 15(1): 184-209, jan/jun. 2017 (ISSN 1678—698X) http://www.periodicos.rc.biblioteca.unesp.br/index.php/estgeo 
funciona como espécie de "antítese" ao desenvolvimento, isto é, surgem em lugares no qual os impactos ambientais e o desrespeito à biodiversidade são alarmantes.

Este traço é comum em todas as regiões do Brasil, para Evaristo de Castro Junior et. ali (2009), o modelo de conservação forjado no Brasil distingue substancialmente daqueles de outros lugares, sobretudo, os modelos advindos dos Estados Unidos. A primeira diferença refere-se aos lugares destinados à conservação. Nos EUA as áreas de conservação foram decretadas "preferencialmente em locais não ocupados pelos colonizadores", enquanto que "no Brasil priorizou-se a ocupação de áreas onde havia concentração populacional e de atividades humanas para a conservação de ecossistemas remanescentes" (CASTRO JUNIOR, COUTINHO, FREITAS, 2009, p. 39). Em outras palavras, a necessidade de preservar se dá devido ao avanço sistemático dos usos espoliativos da diversidade biológica do país.

A territorialização da conservação se dá justamente naquelas áreas mais dinâmicas economicamente ou para aqueles para o qual migrou a fronteira agrícola como o Norte de Minas Gerais. Com efeito, enquanto a ideia original de conservação nos grandes parques nacionais visava impedir impactos futuros, "[...] os parques brasileiros buscaram proteger áreas de interesse ambiental de impactos imediatos, de conflitos já existentes". As políticas e as medidas destinadas a conservação ambiental em terras brasileiras têm em seus genes traços de "conflitos territoriais e de acesso a recursos" (CASTRO JUNIOR, COUTINHO, FREITAS, 2009, p. 39).

$O$ efeito deste traço particular da conservação da natureza reflete nas formas de pensar, criar e gerir as áreas de proteção ambiental. Com isto, os mecanismos de "planejamento e ação propositiva sempre estiveram em segundo plano diante da emergência de questões de proteção, pois os parques são estabelecidos em locais de grande interferência socioeconômicas espaciais de desenvolvimento capitalista" (CASTRO JUNIOR, COUTINHO, FREITAS 2009, p. 39-40). Assim, fica em evidência que as áreas de conservação, de uma forma ou de outra, atuam como medidas compensatórias pelo mau uso/gestão/manejo dos recursos naturais, e por isso esta rede discursiva de valorização do Cerrado passa sempre pelas UCs.

Além das UCs funcionarem como espaços de antítese a usos espoliativos, é preciso ponderar também outros fatores quando se refere propriamente ao Cerrado, e ao Norte de Minas, a criação de UCs, a positivação da natureza e a sua conservação estão intricados também ao processo de globalização. A globalização abarca o Cerrado tanto no setor produtivo quanto nas medidas voltadas à conservação da natureza. Conforme Silva (2009) trata-se de um novo processo de modernização, cujas bases estão situadas em escala global. Este período é caracterizado pela presença em rede das empresas transnacionais do setor agroindustrial, mas também pela presença constante de ONGs e organismos internacionais de conservação da natureza. Tais redes de instituições supranacionais articulam 0 domínio sobre diversos setores e articulam 0 agronegócio, financiamento, fornecimento de máquinas e insumos, pesquisa, produção, etc. a lógica do capital flexível, por um lado, biodiversidade, conservação, criação de UCs etc., por outro.

Nesse sentido, quando deparamos com um conjunto de UCs como aquelas do MSVP, não podemos ligá-las simplesmente às logicas locais ou regionais. Evidentemente, os conflitos e a degradação ambiental a nível regional assumem relevo neste processo, mas o cenário político nacional e internacional também é salutar nesta compreensão. Em outras palavras, embora a conservação da natureza, os mecanismos de proteção à biodiversidade se deem em escala local ou

Estudos Geográficos, Rio Claro, 15(1): 184-209, jan/jun. 2017 (ISSN 1678-698X)

http://www.periodicos.rc.biblioteca.unesp.br/index.php/estgeo 
regional, às vezes, os interesses e os interessados são agentes de outras escalas, nacionais e internacionais. E com isso, a conservação da natureza por meio de UCs acaba por ser a representação concreta, ou melhor, a empiricização destes interesses.

A partir deste quadro interpretativo, podemos supor que a criação de inúmeras UCs na região Norte de Minas a partir do final da década de 1980, obedece a uma rede discursiva - a positivação dos atributos biológicos, hidrológicos, morfológicos e etc. do Bioma Cerrado como um todo. Tal positivação desdobrou-se em uma série de medidas no intuito de "conter" os usos espoliativos e reservar parte desta diversidade natural por meio das UCs. Mas, considerar apenas este aspecto é reducionismo. É preciso situá-lo dentro das dinâmicas do processo de globalização das questões ambientais e das políticas e projetos de conservação da natureza. Este processo é guiado pela relevância que a biodiversidade e a sua conservação assume no cenário geopolítico contemporâneo.

Este processo contribuiu para o reconhecimento da megadiversidade da região na qual o MSVP está inserido, e também nas medidas que levaram à criação de um número relevante de UCs. A região é um mosaico paisagístico multivariado de transição entre o Cerrado e a Caatinga, com características específicas como a Mata Seca. Na paisagem predomina cavernas, chapadas, veredas e nascente de variados rios, etc. Enfim, se junta no mesmo lugar as duas tendências da conservação: avanço dos usos espoliantes da biodiversidade via os projetos de desenvolvimento econômico aliado à riqueza da megadiversidade Norte mineira.

A partir do mapa 1, é possível observar que as UCs que compõe MSVP estão divididas em diferentes categorias de manejo e gestão da conservação. A título de exemplo, entre as 14 UCS, há quatro RPPNs sob a gestão de empresas e fazendeiros, três APAs, uma RDS e cinco unidades de proteção integral. O território é constituído por onze municípios, 10 no estado de Minas Gerais e um no estado da Bahia. 
MAPA 1: A composição territorial e as categorias de Unidades de Conservação do Mosaico Sertão Veredas Peruaçu

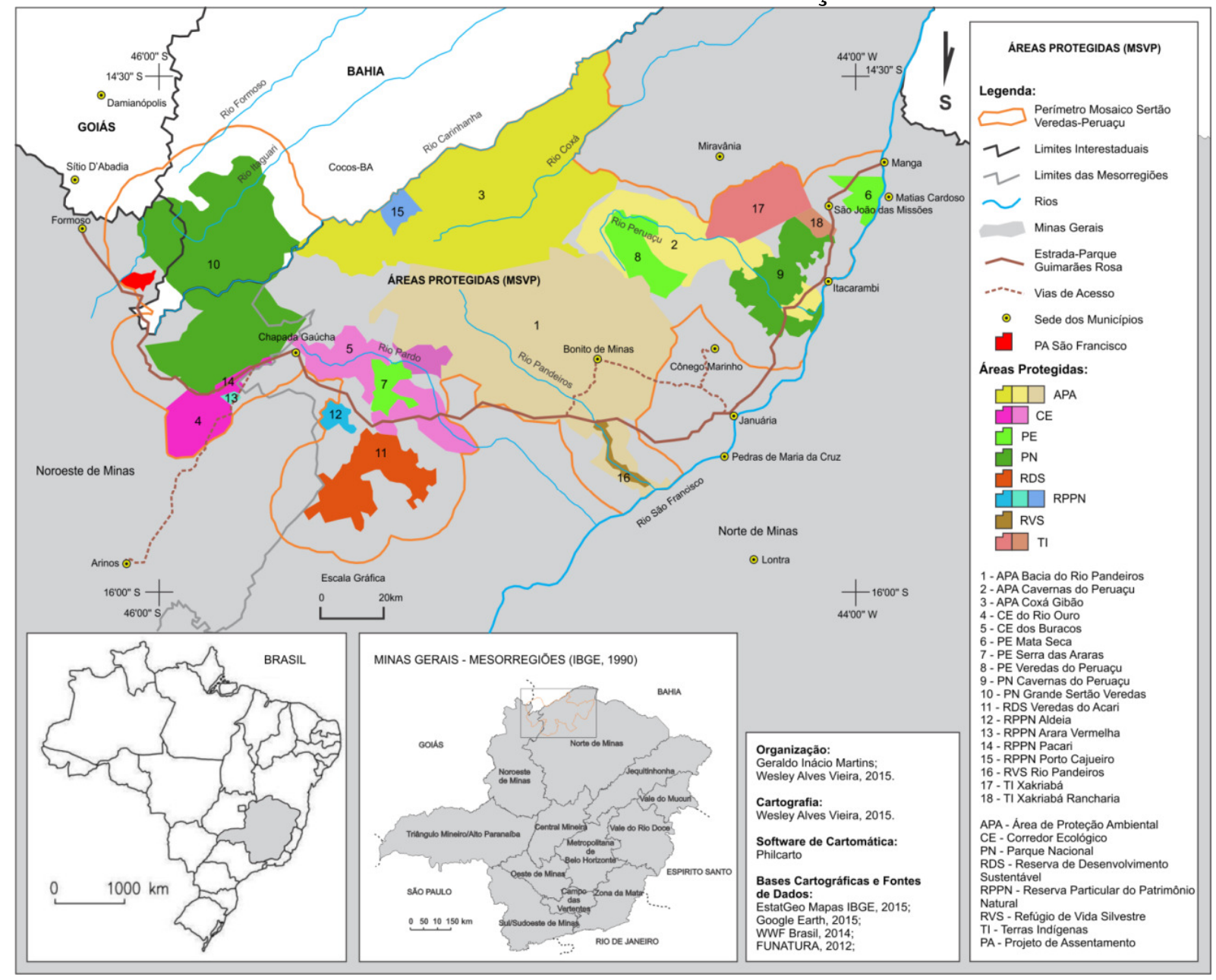

O mapa 1 coloca em tela a importância e a dimensão dos recortes espaciais das UCs. Demonstra, ainda, as diversas UCs e as suas respectivas categorias de manejo, a localização da terra indígena, enfim, as principais unidades territoriais e ambientais de composição do MSVP. A integração dos diversos mecanismos de conservação permite a não fragmentação dos habitats por meio do isolamento das UCs, considerando que o MSVP integra também os corredores ecológicos e áreas de amortecimento. Isto cria a possibilidade de migração de espécies, não se produz o efeito ilha sobre as populações de animais e plantas (não isola estas populações evitando perdas na variabilidade genética).

Vários eventos nos ajudam a entender a história destas UCs. Conforme o item que se segue, questões como a compensação ambiental institucionalizada, presente nos PE MS e PARNA CP, transitando pela conversão de dívida externa para fins ambientais, passando por parcerias entre ONGs para a criação de RPPNs, e chegando, finalmente, as UCs de uso sustentável, vários interesses e interessados se coadunam neste processo. Não podemos reduzir a criação destas UCs a um único elemento, como por exemplo, a degradação ambiental. As UCs representam um projeto de natureza e também a forma como se representa esta natureza em uma determinada sociedade. 
O item que se segue procura delimitar e analisar os processos inerentes à historicidade e a genealogia da criação das UCs que compõem o MSVP, cujo intuito é evidenciar a mesclagem de interesses na criação de UCs de proteção integral.

\section{AGENTES DA CONSERVAÇÃO DA NATUREZA: INTERESSES E CONTROLE DOS FUNDOS TERRITORIAIS}

A intenção deste item é demonstrar como as premissas apresentadas anteriormente se materializam na biorregião do MSVP. A primeira questão que defendemos é que a conservação atende a interesses e sujeitos. Isto é uma constante quando se propõe a analisar as UCs como mecanismo de modulação e produção de diferenciação espacial. Este processo se revela nos mecanismos de conversão de dívida externa e as medidas de compensação ambiental na criação de UCs de proteção integral durante as décadas de 1980 e 1990.

Ao nosso olhar, a conservação materializa interesses múltiplos e estratégias diversificadas na biorregião do Mosaico Sertão Veredas Peruaçu, desde a atuação de empresas, como a Usina Coruripe na criação de RPPNs, passando pelos mecanismos de compensação ambiental do Projeto Jaíba e da Fiat Automóveis, até os mecanismos de conversão da dívida externa no PARNA GSV. Estes fatores se juntam as políticas ambientais de conservação na modulação do espaço e na produção de diferenciações espaciais.

Para efeito de exposição dividimos este item conforme as categorias de manejo e os processos subjacentes à criação das UCs. Assim, primeiramente discutiremos as UCs de proteção integral criadas enquanto medidas de compensação ambiental e conversão da dívida externa. Em seguida, discutimos as UCs de uso sustentável, sobretudo, as RPPNs, bem como, os sujeitos e processos envolvidos no processo.

\section{COMPENSAÇÃO AMBIENTAL E AS UCs DE PROTEÇÃO INTEGRAL NO MSVP}

A compensação ambiental tem duas faces entre as Unidades de Conservação do MSVP, atuando tanto na criação como no planejamento e gestão. No primeiro caso, situa o Parque Estadual da Mata Seca (PARNA MS), criado enquanto mecanismo de compensação ambiental do Projeto Jaíba através de investimentos da Companhia de Desenvolvimento do Vale do São Francisco - CODEVASF; e o segundo caso, o Parque Nacional Cavernas do Peruaçu (PARNA CP) que foi financiado pela Fiat Automóveis. É preciso esclarecer os mecanismos de compensação ambiental jurídica e conceitualmente, para em seguida analisar os dois casos empíricos.

A compensação ambiental está diretamente ligada ao conceito de impacto ambiental. Antes de 1980, havia um vazio jurídico e analítico quando se referia aos impactos ambientais de grandes projetos de desenvolvimento. A compensação ambiental entra como norma jurídica a partir da Lei 6.938/1981 que cria o Plano Nacional de Meio Ambiente, na qual a reparação de um dano ambiental é um mecanismo para diminuir ou cessar o prejuízo causado a coletividade. Com isto, a premissa básica é restituir o equilíbrio anterior ao empreendimento e a tentativa de compensar as "vítimas" pelo mal sofrido, conforme Bechara (2009). Mas, é somente com a Resolução 10 de 1987, substituída pela Resolução 02 de 1996 do Conselho Estudos Geográficos, Rio Claro, 15(1): 184-209, jan/jun. 2017 (ISSN 1678-698X) 
Nacional do Meio Ambiente - CONAMA, que empreendimentos de significativo impacto ambiental ficam sujeitos e responsáveis juridicamente por medidas de compensação ambiental.

De acordo com Bechara (2009), certos empreendimentos são indispensáveis ao desenvolvimento da sociedade, mas não se pode justificar que toda a coletividade suporte os danos ambientais decorrentes de sua implementação. Quando o impacto pode ser evitado com uso de tecnologias, por exemplo, a orientação geral das normas jurídicas é evitar qualquer dano ambiental. Mas, quando isto não é possível, é preciso restituir o equilíbrio ambiental, e como evidenciado nas duas passagens citadas acima, Resolução do Conama e Sistema Nacional de Unidades de Conservação da Natureza - SNUC, o objeto de compensação ambiental adotado para os grandes empreendimentos é, preferencialmente, a criação de UCs de proteção integral.

Uma questão que deve ser pontuada, é que a compensação ambiental não foi instituída juridicamente "para autorizar toda sorte de poluição e impactos negativos ao meio ambiente" (BECHARA, 2009, p. 166). Isto quer dizer que a compensação ambiental não existe para retirar do empreendedor as obrigações legais para mitigar ou eliminar os impactos negativos de suas atividades sobre o ambiente. Por isto, "para se aplicar a compensação ambiental, é preciso primeiro constatar a impossibilidade técnica ou social da extirpação dos possíveis impactos" (BECHARA, 2009 , p. 167). Aqueles impactos não mitigados tecnicamente, ou quando não são evitáveis é que serão objetos de compensação ambiental.

Estas questões se tornam latentes na expansão do Projeto Jaíba, o Jaíba II, sobretudo, devido aos marcos institucionais ligados à questão ambiental desenvolvidos no interstício entre a primeira e a segunda etapa do Projeto. A segunda fase do Jaíba inicia-se oficialmente em 1999, mas condicionada à Licença de Operação - LO ${ }^{3}$, imposta pelo Conselho de Políticas Ambientais - COPAM. Isto é, o desenvolvimento do Jaíba estava condicionado a uma série de políticas de compensação pelos impactos causados ao ambiente. De certa forma, estes condicionantes colocam as questões ambientais, questões ligadas ao manejo/preservação dos recursos naturais no bojo das questões de desenvolvimento econômico.

A primeira questão que se coloca ao refletir sobre as UCs de compensação ambiental do Projeto Jaíba, sobretudo, o PE MS, é sobre a apropriação maquínica do conceito/prática conservação e a internalização dos custos ambientais para as populações locais. A lógica posta, como argumenta Barbosa e Santos (2008, p. 19), é a de "efeito neutro' de destruir para preservar, reduzindo a questão ecológica à lógica capitalista de mercado". E quando se trata, especificamente, da internalização dos custos ambientais, as normas jurídicas, Conama e SNUC, perpetuam este paradigma ao dar ênfase na compensação ambiental à criação de UCs de proteção integral. E no fato de não colocar em questão os rebatimentos e os conflitos que tais espaços destinados à conservação como medida de compensação ambiental podem gerar na escala do lugar, isto é, não colocam em relevo "os custos" sociais da conservação.

Com isto, os custos da compensação ambiental são internalizados. E são internalizados também porque há flexibilidade nos procedimentos de compensação

\footnotetext{
${ }^{3}$ De acordo com as normas internas do Copam LO autoriza "a operação da atividade ou empreendimento, após fiscalização prévia obrigatória para verificação do efetivo cumprimento do que consta das licenças anteriores, tal como as medidas de controle ambiental e as condicionantes porventura determinadas para a operação" (SEMAD, 2013, s/p).

Estudos Geográficos, Rio Claro, 15(1): 184-209, jan/jun. 2017 (ISSN 1678—698X)

http://www.periodicos.rc.biblioteca.unesp.br/index.php/estgeo
} 
ambiental, com prorrogação de prazos, atenuação de multas e/ou não cumprimento dos condicionantes pelos empreendedores. Isto prolonga os efeitos negativos dos impactos ambientais sobre a vida das populações locais. Questões que podem ser verificadas pela falta efetiva de Planos de Manejo das UCs do Sistema de Áreas Protegidas - SAP do Jaíba, que resulta na falta de clareza de como/para quem/porque e o que conservar.

Outro desafio colocado quando se cria uma UC de proteção integral é a questão da regularização fundiária. A premissa básica é que o Estado adquira as áreas atingidas pela conservação via desapropriação. Com isto, surgem os problemas para desenvolver este processo, sobretudo, no que refere à titularidade e o levantamento das áreas atingidas. Esse procedimento é essencial porque uma "UC existe em pleno direito quando possui limites definidos e quando o Estado territorializa este espaço, exercendo sobre ele a soberania, o que só é possível quando a posse e o domínio sejam públicos" (SATHLER, 2010, p. 40).

Este processo de "territorialização" se coloca de maneira singular nas UCs do SAP do Jaíba, conforme o relatório parcial do cumprimento das condicionantes ambientais em 2006: (i) somente 3.500 hectares de terras foram transferidos da Ruralminas para o Instituo Estadual de Florestas para efetivar as UCs do Jaíba; (ii) e 1.471 hectares de terras estão em fase final de transferência da CODEVASF, para o IEF; nas demais áreas com o mesmo objetivo; (iii) é preciso proceder a desapropriação, mas, o "Estado encontra entraves para iniciar este processo, em especial quanto ao levantamento das áreas afetadas"; (iv) é "fundamental a correta descrição de cada propriedade a ser adquirida". E, em alguns casos, há "divergências entre as áreas registradas e as medidas", há "problemas desta natureza em todas as propriedades a serem desapropriadas" (GOVERNO DE MINAS GERAIS, 2006, p. 13).

Outro exemplo da relação entre a compensação ambiental e a criação e o planejamento de UCs ocorre no PARNA CP e a Fiat Automóveis S/A. O Instituto Brasileiro de Meio Ambiente e dos Recursos Naturais Renováveis - IBAMA, autuou a Fiat em 1995 pelo descumprimento da Resolução № 18 de 1986 do CONAMA que dispõe sobre a poluição do ar por veículos automotores. O Auto de Infração aplicado à Fiat (nº. 08112.000968/94-11) deu-se devido à produção e à comercialização de veículos que descumpriam a legislação ambiental entre os anos de 1993 e 1995. A multa aplicada equivale, caso fosse quitada, em termos atuais a $R \$ 4.573,535,00$ ou \$ 4.318,73 por cada dia de descumprimento da legislação.

Conforme o Decreto 99.274 de 1990, as multas aplicadas podem ser suspensas quando o infrator, por meio de termo de compromisso e aprovado pela autoridade que aplicou a multa, se comprometer com medidas para cessar ou corrigir a degradação ambiental. Inicia-se então o envolvimento da FIAT Automóveis S/A com a criação e planejamento do PARNA CP em 1997, com a assinatura do Termo de Compromisso - TC com o Ministério Público Federal e com o IBAMA. Entre outras medidas que deveriam ser adotadas pela empresa, destaca-se a "(...) aquisição de gleba de terra e montagem de infraestrutura necessária à criação de um Parque Nacional na área de 6.000 ha. (...) localizada no interior da Área de Proteção Ambiental 'Cavernas do Peruaçu', no Estado de Minas Gerais (...)" (TERMO DE COMPROMISSO/MINISTÉRIO PÚBLICO FEDRAL, 1997, folha 284).

Além das terras, a FIAT Automóveis S/A deveria também ser a responsável pela criação do Plano de Manejo do parque que seria criado, bem como, arcar com os custos das obras infraestruturais básicas para a criação da UC. Em 1999, a empresa adquiriu aproximadamente 12.000 hectares de terras, no valor de $\mathrm{R} \$$

Estudos Geográficos, Rio Claro, 15(1): 184-209, jan/jun. 2017 (ISSN 1678—698X)

http://www.periodicos.rc.biblioteca.unesp.br/index.php/estgeo 
5.400.000,00, mas destes, apenas 2.350 hectares era referente à área do polígono (área na qual se encontra os principais elementos para a conservação) como demandava o TC. Apesar disso, deu-se início a criação do PARNA CP que, oficialmente, foi reconhecido pelo Decreto de 21 de setembro de 1999. Com a área de compensação ambiental, no total, este parque tem o equivalente a 56.800 ha.

Além das terras, a FIAT Automóveis S/A deveria também entregar o "plano diretor" ou Plano de Manejo, mas isso se aplicava somente a área doada conforme o TC, ou seja, os 6.000 hectares. Em negociação com o Mistério Público e o IBAMA, a empresa aceitou fazer o plano de todo o Parque e, assim, em 2005, apenas seis anos após sua criação, o PARNA CP tinha o seu Plano de Manejo. Se comparado às demais UCs do MSVP, nota-se a rapidez do processo, o PARNA GSV, por exemplo, demorou quatorze anos para ter concluído o seu Plano de Manejo, e as demais UCs, exceto as RPPNs, ainda não tem o plano.

Mesmo com as terras adquiridas e com o Plano de Manejo entregue em 2009, - Ministério Público Federal convocou a FIAT Automóveis S/A e o ICMBIO para verificar o desenvolvimento do processo. Esta convocatória aconteceu por dois motivos: a efetiva regularização fundiária e a construção dos equipamentos de infraestrutura. No que se refere à regularização fundiária das terras adquiridas pela empresa, o problema fundamental encontra-se descrito na Instrução Normativa nº 09, publicada em 2003, estabelecendo critérios para a regularização fundiária em UCs federais.

Tal instrução demanda "a prova inequívoca da autenticidade e da legitimidade do título de propriedade ostentado e da boa-fé da ocupação e das benfeitorias edificadas, quando se trata de domínio privado e de posse reivindicados nas unidades de conservação" (IBAMA/MMA, 2003, s/p). Em outras palavras, a posse da terra e regularização fundiária se daria mediante a comprovação de títulos da propriedade com a cópia da aquisição original ou certidão que comprove o domínio privado do imóvel. As terras adquiridas pela FIAT Automóveis S/A não possuíam tal documentação e, portanto, a regularização entravou. Em consequência, todos os encaminhamentos complementares também, desde a construção das infraestruturas necessárias até a abertura do parque a visitação pública.

A relação entre degradação ambiental e as medidas de compensação ambiental podem ser compreendidas dentro do paradigma da internalização das externalidades ambientais. Dentro deste paradigma, conforme Carlos M. A Gonzaga (2013), externalidades ocorrem quando um indivíduo ou um grupo é impactado sem receber qualquer tipo de compensação. A proposta é que o Estado crie mecanismos capazes de influenciar o comportamento dos agentes produtores de tais impactos, cujo objetivo é corrigir as externalidades negativas. Este mecanismo é conhecido como "princípio do poluidor pagador", o PNMA e as políticas de compensação ambiental derivaram deste princípio.

Para este autor, existe uma falta de precisão conceitual e isto fica evidente quando refletimos que um "dano ambiental" não é propriamente um "custo" no sentido econômico, haja vista que não é fácil de calculá-lo ou mesmo reduzi-lo a uma simples relação de troca. Em geral, os chamados "custos sociais" levam a "desestabilização da base natural da existência sociocultural das populações tradicionais, desestruturação de ecossistemas". O fato coloca em cheque os cálculos econômicos como medida para se pensar as externalidades e, como consequência, o processo de internalização. Com isso, a noção de externalidade é "um buraco negro do individualismo metodológico" que fundamenta as teorias neoclássicas (ACSELRAD, 1995, p. 134-135).

Estudos Geográficos, Rio Claro, 15(1): 184-209, jan/jun. 2017 (ISSN 1678—698X)

http://www.periodicos.rc.biblioteca.unesp.br/index.php/estgeo 
Não podemos duvidar da importância das empresas públicas e privadas (como o quadro em análise da CODEVASF e FIAT Automóveis S/A) arcarem com as consequências ambientais de suas atividades. No entanto, o ponto de reflexão devese basear no princípio de responsabilidade em detrimento do princípio de precaução. Isto é, dadas as condições socioambientais, os agravamentos dos usos espoliativos - projetos baseados no gerenciamento de riscos (ou princípio de precaução) - tornam-se apenas elementos paliativos. Mais do que lidar com riscos, a demanda é que se parta do "princípio da responsabilidade" (DUPAS, 2006). O elemento latente - e não posto nas políticas de compensação ambiental, mesmo que elas forneçam serviços ambientais como as UCs, - é se realmente os custos sociais e ambientais podem ser compensados. Em que medida as áreas degradadas pelos projetos da CODEVASF na região Norte de Minas Gerais podem ser compensadas?

Evidentemente, todas estas questões fazem parte da história da conservação ambiental, ou melhor, estão na genealogia das UCs criadas enquanto medidas de compensação e, portanto, no ajuda a compreender melhor os diversos componentes conflituosos que abarcam a estrutura do MSVP e das UCs que the dão existência. Outra questão a ser refletida é a relação capital privado, mesmo que seja na situação apontada, e as políticas de conservação. Conforme aponta Mariana França Mungai (2008), os órgãos gestores reconhecem a importância da parceria, aliás, acreditam que sem ela a possibilidade de criação da UC de proteção integral era mínima. Isto acontece devido à falta de orçamentos que, geralmente, afeta todas as UCs no cenário brasileiro. Este fator compromete seriamente as atividades de planejamento e, quando conseguem planejar, faltam os recursos para efetivá-lo. Quando há ausência efetiva do Estado no que se refere ao planejamento e à gestão das UCs, a tendência é que parcerias comecem a surgir.

\section{CONVERSÃO DE DÍVIDA EXTERNA E A CONSERVAÇÃO DA NATUREZA NO MSVP}

Após ter apresentando a conservação intermediada pelas compensações ambientais, suas características e fatores determinantes, cabe agora apresentar a segunda face de interseção entre planejamento, criação e gestão de UCs e o capital "privado" - a conversão de dívida externa para a conservação ambiental, fenômeno que envolve um dos parques mais importantes do MSVP, tanto em extensão, como em implementação do Plano de Manejo, o PARNA GSV. A conversão da dívida envolveu a Funatura, ONG co-gestora do parque, e a TNC, ONG ambientalista com sede nos EUA.

É muito comum a correlação entre dívidas externas e os problemas ambientais dos países em desenvolvimento. Apressadamente, criam-se relações de causa e efeito sem uma reflexão mais aprofundada do assunto. Isto pode ser verificado, por exemplo, quando se afirma que as crises financeiras devido ao endividamento externo é um dos principais elementos para explicar às crises ambientais de países latinos como o Brasil. Evidentemente, não excluímos de imediato esta correlação, mas acreditamos que tanto a dívida quanto as crises ambientais demonstram o esgotamento de um padrão de desenvolvimento adotado por estes países em um ato mimese. A dívida e problemas ambientais têm caráter estrutural e histórico.

Conforme Fábio de Andrade Abdala (2000), de toda esta polêmica, duas questões ficaram claras. As conversões não resolvem o problema da dívida e

Estudos Geográficos, Rio Claro, 15(1): 184-209, jan/jun. 2017 (ISSN 1678—698X)

http://www.periodicos.rc.biblioteca.unesp.br/index.php/estgeo 
também não resolvem o problema das políticas ambientais. Mas, de qualquer forma, as conversões existiram e é preciso compreendê-las. A questão se tornou mais latente na década de 1980, quando a crise da dívida dos países latinos americanos teve o ponto auge (ABDALA, 2000). Dada a situação de "insolvência financeira", e dadas as características de agroexportador de tais países, surgem as correlações entre a dívida e a degradação. Em outras palavras, os países latinos, para arcarem com os compromissos no mercado externo, têm que expandir o circuito produtivo, o que equivale a usar mais terras, a desmatar mais florestas, enfim, aumentar a pressão sobre os serviços ambientais.

Segundo Abdala (2000), os "[...] efeitos ambientais das políticas governamentais relacionadas com a dívida é a que relaciona a intensificação da exploração de recursos naturais à multiplicação de divisas para pagar os serviços da dívida externa" (ABDALA, 2000, p. 66-67). O autor, aliás, revela como estas situações se deram no Chile, Bolívia e Costa Rica, etc., e mais, esclarece como as conversões para fins ambientais ampliou tal processo. Ao final, Abdala pondera que tais efeitos negativos têm mais a ver com a estrutura política interna e com o desgoverno no que se refere às políticas ambientais, do que com a dívida propriamente.

As conversões são multivariadas. Abdala (2000) apresenta as experiências bem sucedidas e também as que foram malsucedidas. Segundo ele, para o insucesso concorrem dois fatores - a falta de acordo entre políticas ambientais e econômicas e o tipo de transação realizada. A respeito das modalidades de transações, Ricardo Ubiraci Sennes (1993) destaca as mais comuns: debt-debt swap, debt-equity swap, debt-trade swap debt-for-nature swap. Para o objeto em análise destacamos apenas: debt-trade swap, debt-for-nature swap.

O Brasil sempre tratou as conversões com desconfiança, pelo menos até a década de 1990. Entre os argumentos para isso, encontramos desde aqueles relativos à soberania nacional, até aqueles ligados às questões inflacionárias. A proximidade da realização da Eco-92, a pressão internacional sofrida desde a década de 1970 e, sobretudo, a pressão das ONGs nacionais contribuíram para abrir as discussões referentes ao tema. Finalmente, em 1991, o governo brasileiro aprovou o "Plano de Conversão da Dívida para fins Ambientais". Este objetivou adicionar recursos externos aos escassos investimentos internos às políticas ambientais.

Ainda no ano de 1990, formou-se o consórcio de ONGs brasileiras para elaborar os projetos para os fins de conversões. Elas chegaram ao montante de US\$ 264,3 milhões de dívidas passíveis de serem convertidas. Em 16 de Julho de 1991, o Banco Central publicou a Resolução no. 1840, no qual orientava as modalidades de conversão. Nesse sentido, ficou determinado que o programa de conversões brasileiras permitiria a entrada de fundos para geração de rendimentos para a aplicação em programas de conservação da natureza.

Conforme Abdala (2000), este mecanismo de conversão funcionaria da seguinte forma: primeiramente, instituições sem fins lucrativos que atuassem no Brasil, poderiam receber doações de entidades públicas e privadas estrangeiras, na modalidade de créditos, títulos e depósitos. Após o recebimento das doações de títulos da dívida e depois da transferência destes ao Banco Central, que aplicaria tais títulos no Fundo Ambiental Nacional, os rendimentos, equivalente a $6 \%$ ao ano e mais a variação cambial, seriam destinados à instituição brasileira que recebeu a doação. 
A definição de quais os projetos deveriam ser contemplados ficou sob a responsabilidade de uma comissão constituída por membros do governo, ONGs e pesquisadores. A prioridade destas conversões eram os projetos ligados à conservação da biodiversidade, meio ambiente urbano, energia, conservação e uso sustentado dos recursos, educação ambiental e desenvolvimento sustentável (ABDALA, 2000). A primeira experiência de conversão de dívida para fins ambientais foi, justamente, a experiência do PARNA GSV que surgiu da parceria da Funatura com a TNC.

$\mathrm{Na}$ prática, as conversões possibilitaram à Funatura, orçamento para gerir o PARNA GSV por vinte anos. Diante da escassez de recursos destinados às UCs, isto se revela um ponto de extrema importância. Além disso, a parceria com a TNC foi essencial para o levantamento socioeconômico das populações que viviam no interior da unidade, bem como em atividades para levantar a riqueza da biodiversidade. Somam-se $a$ isso os programas de educação ambiental desenvolvidos pela ONG na década de 1990, e programas ligados à medicina e à saúde.

Em nível de instituição, para a Funatura, envolvida com o PARNA GSV desde os levantamentos para a sua criação no final da década de 1980 , a conversão permitiu ampliar a estrutura administrativa e os equipamentos de conservação e de fiscalização. Conforme destaca Bernardo Ricupero, Abdala e Mariano (1995), isto permitiu à ONG desenvolver projetos estratégicos de médio e longo prazos, considerando os recursos efetivos para dar continuidades a estes (RICUPERO, ABDALA, MARIANO, 1995). Em termos de gestão, o ponto mais significativo foi o repasse da Metodologia da Avaliação Ecológica Rápida da TNC para a Funatura ${ }^{4}$.

Conforme destacam os autores, "o problema com maior destaque refere-se menos às conversões propriamente ditas, mas, sobretudo quanto à situação da população que vive neste Parque Nacional" (RICUPERO, ABDALA, MARIANO, 1995 p. 25). Além disso, quando realizávamos, entre os anos de 2009 e 2011, a nossa pesquisa de mestrado, observamos o problema mais de perto. Desde o início da década de 1990, as populações atingidas pelo PARNA GSV sofreram múltiplos processos de rompimento do seu modo de vida devido ao cerceamento cada vez mais efetivo forjado pela gestão das UCs. Este cerceamento resultou na remoção das 90 famílias que viviam no parque para o PA São Francisco e Gentio no início da década de 2000. Tal PA tem condições precárias desde o tipo de solo e até mesmo a área de sua localização.

Este remanejamento se deu graças à fragilidade territorial das comunidades camponesas que lá viviam, em sua grande maioria, posseiras. Quando foram remanejadas, somente as "melhorias" (casas, currais, etc.) foram indenizadas. A saída das áreas de domínio do parque deu-se devido às imposições que foram se firmando, entre elas, a dificuldade de abrir novas áreas para a agricultura e para a solta de gado. Dada a falta de opção, somente duas eram possíveis, ou migravam para as cidades mais próximas, ou iam residir no PA.

A relação estabelecida por meio de ONGs nacionais e internacionais para conservação da natureza é um dos principais motes de críticas em relação às conversões de dívidas. $O$ foco das críticas se situa, sobretudo, no escopo e modelos de conservação que estas ONGs acabam por impor às suas parceiras em outros países. Em outras palavras, a proposta de conservação destas entidades é mais

\footnotetext{
${ }^{4}$ Mecanismo flexível utilizado para obter e aplicar, em ritmo acelerado, informações biológicas e ecológicas com o intuito de promover ações de conservação.

Estudos Geográficos, Rio Claro, 15(1): 184-209, jan/jun. 2017 (ISSN 1678—698X)

http://www.periodicos.rc.biblioteca.unesp.br/index.php/estgeo
} 
conservadora em relação ao padrão de conservação almejado, a presença de populações humanas e estratégias de manejo. Este escopo acaba sendo absorvido pelas ONGs nacionais, como a Funatura, por exemplo, e daí a conflitualidade e as contradições emergem. E umas das consequências disso é o tratamento dado às comunidades atingidas, como é o caso dos veredeiros do PARNA GSV, que viram as suas condições de reprodução diminuírem sensivelmente, à medida que a implementação do parque ganhava concretude.

Aliado e complementar a esta primeira ressalva, encontra-se uma segunda, aquela referente aos interesses nacionais da conservação. Como nos apresenta Abdala (2000), as conversões, geralmente, alocam recursos em projetos que podem atender as agendas internacionais da conservação, e colocam em segundo plano os interesses nacionais e mesmo as necessidades ambientais locais. Ao lado destas questões, colocam-se os elementos de natureza histórica como, por exemplo, ao questionar se, na verdade, as conversões não estariam legitimando dívidas construídas de forma perversa.

Waldman (1992, p.7), ao referir-se a Cândido Grzybowsk, afirma que "por trás da dívida externa e da questão ambiental, está o modelo de desenvolvimento, sua base tecnológica e organização social da produção, (...), as políticas, as leis, normas e instituições sociais que regulam os conflitos inerentes ao modelo de desenvolvimento", e aceitar a política das conversões é também legitimar este processo. Nesse sentido, "a dívida é ecologicamente inconvertível, pois ela é, em si mesma, antiecológica” (WALDMAN, 1992, p.11).

As questões levantadas pelo autor são pertinentes, sobretudo, se observarmos a dívida externa pelo ângulo histórico. Em uma primeira análise, como destacamos, estas parcerias ajudam a fomentar os projetos de desenvolvimento das UCs, dada a falta de recurso por parte do Estado para este fim. Em uma segunda análise, e observando o PARNA GVS, trata-se de pensar os diferentes projetos para a natureza e para a conservação. Em outras palavras, o PARNA GSV é o cenário e/ou ponto de encontro de múltiplos projetos de natureza. Primeiramente, tem-se o imbricamento entre Funatura e IBAMA, e disso surge a imagem ideal da natureza a ser conservada - a de proteção. À medida que este conjunto de relações se complexifica, novos sujeitos entram na rede de interesses, este projeto se modifica, e a conservação se torna um campo de disputa e interesses.

A disputa não é para definir o que conservar, mas a quem esta conservação vai servir e a que interesses. Vimos que as populações locais são excluídas, e com isto, o PARNA GSV tornou-se objeto de interesse alheio a qualquer relação com a escala local. Aí processa o caráter multiescalar da conservação, embora ela se dê no plano local, nela se imbricam interesses do regional/nacional e global. A conservação no PARNA GSV, finalmente, obedece muito mais a ordens distantes do que a ordens próximas.

Em outras palavras, é importante o fortalecimento dos mecanismos de conservação e, sobretudo, a garantia de investimentos para isso, mas à medida que - Estado se abstém desta função, a pergunta passa a ser: a quem atende os objetivos de conservação do PARNA GSV? Não é demais salientar que o fortalecimento desejado não pode se dar de maneira pessoalizada como acontece com a Funatura - conclusão que se pode tirar das análises dos fragmentos acima. Além disso, é preciso destacar a contradição deste processo, as ONGs fortalecidas, conforme Abdala (2005, p. 103), são "aquelas com vínculos íntimos com o Estado, ou àquelas com "funcionários" em seus quadros". Com isto, o fortalecimento 
requerido é parcelar e restringir os benefícios financeiros a instrumentalização da ONG.

A falta de investimento na efetiva implementação do PARNA GSV e as parcerias de cogestão, abriu espaços para parcerias com a Funatura e, daí por diante, abriu caminhos para a confluência de vários sujeitos interessados em subsidiar as atividades desenvolvidas nesta UC. À medida que estas parcerias aumentaram, aumentou também o distanciamento do próprio Estado na condução do interesse público que seria, no caso, a conservação para o bem comum. Assim, no PARNA GSV se mesclam os interesses daquelas instituições que Antônio Carlos Diegues (2008) denomina de as "multinacionais da conservação", a WWF e, sobretudo, a TNC, mas os interesses nem sempre claros - Fundação O boticário, Pathfinder, etc.

No que se refere às "multinacionais da conservação", é preciso ponderar que estas têm influência nas políticas ambientais como um todo mas, na relação aqui apresentada, é possível percebê-la empiricamente. Conforme Diegues (2008), os modelos de conservação propostos pelas grandes ONGs tendem a excluir a participação da população interessada nos modelos de gestão e de manejo da natureza. Além disso, impõem modelos de ciência e de práticas conservacionistas. $E$, por fim, acabam influenciando as ações das ONGs locais na condução das práticas de conservação e em relação às populações residentes em áreas de parques (vejamos, por exemplo, a metodologia adotada pela Funatura em parceria com a TNC e o desfecho final da regularização fundiária do PARNA GSV).

Quando se trata das políticas de conversão da dívida externa para fins ambientais e a forma como isto se materializa no PARNA GSV, são sintomáticos os interesses envolvidos. O PARNA GSV, entre todas as UCs do MSVP, é o local das mais variadas pesquisas em levantamento de répteis e catalogação de plantas e animais. É curioso notar que estes subsídios para a conservação não têm como escopo o fortalecimento das UCs de uso sustentável, justamente quando há a possibilidade da conservação acontecer de forma mais justa, sem precarizar as condições de reprodução de vida das populações atingidas.

O item seguinte trata de outra modalidade de conservação, as UCs de uso sustentável. Nele discutimos os arranjos sucessivos e conflituosos operantes também nesta modalidade de conservação.

\section{INTERESSES PRIVADOS E AS RPPNs}

As RPPNs surgem na legislação brasileira em 1990, por meio do Decreto de no 98. 914, posteriormente substituído pelo Decreto de nํ. 1.192 de 1996. Estas correspondem, de certa forma, ao desdobramento das Reservas Particulares da Flora e Fauna criadas em 1988. A RPPN, segundo o SNUC, "é uma área privada, gravada com perpetuidade, com o objetivo de conservar a diversidade biológica". Entre os objetivos destas, destacam-se as pesquisas científicas e as atividades ligadas ao turismo, eventos recreativos e educacionais (BRASIL, 2000, s/p).

Idealmente, as RPPNs devem ser UCs complementares àquelas criadas e geridas pelo Estado, cujo intuito é criar Zonas de Amortecimento e Corredores Ecológicos. Para os detentores das RPPNs, empresas, produtores do agronegócio, estas podem representar uma importante estratégia, além, é claro, da conservação da natureza. Conforme Luci Ayala (2010, p. 11), "para os diversos setores empresariais, criar e manter reservas naturais (...), é uma iniciativa eficaz de 
direcionamento de investimentos em ações ambientais efetivas, indo além do marketing ecológico propriamente dito".

No que se refere ao agronegócio, "a presença de reservas do ambiente natural tem impacto direto em suas atividades, pois contribui para o equilíbrio ecológico, com o controle biológico de pragas e a conservação dos recursos hídricos" (AYALA, 2010, p. 11). Segundo esta autora, as RPPNs agregam valores a produtos e serviços e isto abre espaço para o relacionamento entre as empresas e o seu público. Estas também podem representar uma estratégia e oportunidades de negócios para as empresas, considerando o quadro propício estimulado pelas mudanças climáticas provocadas pelo aquecimento global.

Nesse sentido, "a recuperação de ambientes florestais e a conservação de florestas em pé - desde que documentadas nos planos de manejo das RPPNs podem ser transformadas em créditos de carbono por meio de projetos de sequestro de carbono da atmosfera" (AYALA, 2010, p. 11). Enfim, das questões apresentadas pela autora, a conservação da natureza representa uma boa estratégia para os mais diversos seguimentos empresarias.

Valeska Buchemi de Oliveira et. ali (2010) nos apresenta o outro lado das RPPNs, enquanto instrumento importante na preservação da biodiversidade. Apesar das RPPNs geralmente ocuparem pequenas áreas, para autora, elas contribuem para a conservação em larga escala, "ou escala regional". Isto porque elas ajudam na criação de corredores que aumentam a conectividade de paisagens em áreas fragmentadas. Em outras palavras, as RPPNs, dadas as suas características, funcionam como mecanismo complementar a outras modalidades de UCs e tornamse um elemento estratégico, sobretudo, em áreas fragmentadas, por funcionarem como "trampolins ecológicos".

As RPPNs podem facilitar também a troca de sementes entre habitats permitindo o fluxo de informações genéticas entre indivíduos e populações. Argumentos ecológicos não faltam para explicar a importância das RPPNs: proteção de nascentes de córregos, lagoas, cachoeiras, micro bacias-hidrográficas, proteção da fauna e da flora, elementos geomorfológicos como grutas e cavernas. Outro argumento muito comum é que as RPPNs ajudam aumentar as áreas de conservação dos biomas e para complementar as estratégias regionais de conservação.

Cientes das questões apresentadas e concordando com algumas, adotamos duas posturas. A primeira é que não pretendemos fazer uma análise da importância ecológica das RPPNs que compõem o MSVP. Além disso, procuramos ir para além do discurso da transformação mercadológica e da mercantilização da conservação da natureza. Para nós as RPPNs, sobretudo nas condições analisadas nas UCs do MSVP, representam uma dupla estratégia: de um lado, permitem a existência de grandes propriedades de terras devido à isenção do Imposto Territorial Rural - ITR, aliado ao fato de que estas propriedades tornadas UC de uso sustentável encontram-se em áreas em que o preço do solo é relativamente baixo, dado às restrições de uso devido ao fato destas estarem em áreas de amortecimento. De outro, a criação de uma RPPN nestas condições permite carrear recursos para levantamentos científicos a respeito da flora e fauna e permite, ainda, o marketing ecológico de empresas. Estas premissas serão desenvolvidas, mas antes é preciso uma contextualização.

Até o ano de 1998, a biorregião do MSVP não contava com nenhuma RPPN, a primeira surgiu na área de Mata Seca no município de Manga, no atual polígono do PE da MS (a RPPN Fazenda da Ressaca) Em 2000, mais três RPPNs foram

Estudos Geográficos, Rio Claro, 15(1): 184-209, jan/jun. 2017 (ISSN 1678—698X)

http://www.periodicos.rc.biblioteca.unesp.br/index.php/estgeo 
criadas no entorno do PARNA GSV (mais especificamente as RPPNs Arara Vermelha e Vereda do Pacari em 2004, e RPPN Porto do Cajueiro em 2005). Quais elementos nos ajudam a pensar a historicidade destas RPPNs?

Duas ponderações. Conseguir informações sobre as RPPNs do MSVP foi umas das partes mais difíceis desta pesquisa. Primeiramente, pelas sucessivas negativas de entrevistas e/ou de oferta de qualquer tipo de informação. Em segundo lugar, devido à pouca documentação a respeito destas nos órgãos de regulamentação - IBAMA, Secretaria de Meio Ambiente, etc. Nesse sentido, as informações, quando obtidas, repetiam velhos jargões como, por exemplo, "preocupação com o meio ambiente", sem oferecer nenhuma informação adicional.

Esta situação nos forçou a procurar outras fontes. E desta procura obtivemos a informação de um projeto aprovado pela Funatura para incentivar a criação de RPPNs em volta do PARNA GSV e da Chapada dos Veadeiros. Estamos nos referindo ao projeto Establishment of Private Natural Heritage Reserves (RPPNs) in the Brazilian Cerrado, resultante da parceria com a United Nations Development Programme - UNDP e com a Global Environment Facility - GEF. Desta parceria resultou em duas das RPPNs do MSVP - a RPPN Arara Vermelha e a RPPN Veredas do Pacari.

A partir do acesso ao relatório final deste projeto começamos a desenhar o quadro de análise, mas ainda faltavam informações básicas sobre a RPPN Fazenda Porto do Cajueiro. Sem acesso às informações, começamos a analisar quais eram os fatores que poderiam atrair grandes empresas como Usina Coruripe para a região e quais eram os objetivos da RPPN.

O projeto "Estabelecimento de Reservas Particulares do Patrimônio Natural RPPNs no Cerrado Brasileiro" teve início em 2001, e contou com o apoio financeiro do Programa das Nações Unidas para o Desenvolvimento - PNUD, que financiou US\$ 750 mil, em contrapartida, a Funatura financiou US\$110 mil (PNUD, 2004, $\mathrm{s} / \mathrm{p}$.). O projeto teve como objetivo estimular proprietários rurais na criação e estabelecimento de RPPNs e estabelecer mecanismos de sustentabilidade para estas áreas. Conforme Aline Tristão Bernardes (2006, p. 5), redatora do parecer final da parceria, entre os anos de 2001 e 2005, na busca destes objetivos, foram desenvolvidas atividades de "mobilização e disseminação do instrumento RPPN" por meio de atividades de capacitação e eventos culturais" informando a importância de tais áreas para a conservação da natureza.

Entre as atividades desenvolvidas por este projeto encontram-se aquelas referentes à seleção e a demarcação de áreas potenciais para serem transformadas em RPPNs. A etapa seguinte foi o estabelecimento de parcerias formais entre a Funatura e os proprietários rurais. Cumprida esta etapa, o projeto produziu os documentos técnicos de orientação no manejo destas áreas por meio da Avaliação Ecológica Rápida, informações que subsidiaram os Planos de Manejo. Com isto, os técnicos identificaram os potenciais das áreas que seriam transformadas em RPPNs, no caso daquelas pertencentes ao MSVP. Dada a falta de infraestrutura para o turismo ecocultural, a sugestão foi o desenvolvimento de pesquisas sobre a riqueza da flora e fauna.

O padrão de desenvolvimento econômico baseado no agronegócio nos municípios do entorno de Chapada Gaúcha, Arinos e Januária, no qual situa as duas RPPNs, foi o principal entrave encontrado. Bernardes (2006, p. 13) sublinha que em "territórios ocupados para expansão agrícola como no caso do entorno do PNGSV (PARNA GSV) as dificuldades são enormes". A solução para este entrave deu-se com a averbação de Reservas Legais e a "reconstituição" das APPs. Isto porque as

Estudos Geográficos, Rio Claro, 15(1): 184-209, jan/jun. 2017 (ISSN 1678—698X)

http://www.periodicos.rc.biblioteca.unesp.br/index.php/estgeo 
"RPPNs podem também ser criadas em sobreposição às reservas legais (sic) das propriedades".

Apesar dos eventos adversos, a relatora da parceria conclui que as RPPNs Vereda do Pacari e Arara Vermelha constituem uma importante estratégia de complementaridade a conservação do PARNA GSV. Segundo a relatora, os padrões de usos e a ocupação do solo têm produzido o efeito ilha no Parque, isto é, a conservação da natureza envolta pela produção de soja e de sementes de capim. Para ela, a "paisagem plana da região favoreceu a ocupação por grandes fazendas mecanizadas produtoras de grãos" e, com isso, "muito da rica diversidade da vegetação do Cerrado foi perdida neste processo" (BERNARDES, 2006, p. 13).

Além disso, dada a proximidade das duas RPPNs, foi possível reformar as antigas instalações da fazenda e criar uma sede conjunta para as reservas. A contiguidade das áreas possibilitou, também, a ampliação e a formação de "um maciço de 595,24 hectares (...)" próximo ao PARNA GSV, "configurando corredores de biodiversidade, o que é considerado uma boa estratégia de conservação" (BERNARDES, 2006, p. 16). Enfim, o relatório destaca pontos importantes na condução do projeto Establishment, e o que nos ajuda a compreender a estruturação destas duas RPPNs. Evidentemente, os eventos de natureza política e os interesses envolvidos não aparecem claramente, é preciso ponderar isso, mas antes, traremos a análise da RPPN Fazenda Porto Cajueiro.

A relatora do projeto Establishment informa que além das duas RPPNs criadas, os trabalhos conseguiram averbar mais cinco RL e APPs, áreas potenciais para novas RPPNs. E mais, dadas as atividades de êxito do projeto, a parceria com a Funatura, ficou evidente para os proprietários rurais da região (e de outras regiões) a importância estratégica das reservas. Diante disso, entendemos a RPPN Fazendo Porto do Cajueiro como um processo complementar as atividades do projeto aliado aos interesses de uma grande empresa como a Coruripe. Interesses que manifestam em crédito mais acessível, averbação de reserva legal e parcerias com outras empresas na condução de pesquisas. Vejamos, pois, este quadro de análise.

A Usina Coruripe - do Grupo Tércio Wanderley - tem como base o Estado de Alagoas, mas estendeu suas atividades a região de Cerrados do Triângulo Mineiro/Alto Paranaíba. A relação desta empresa com a criação de reservas remonta a década de 1950, com a criação de uma área 7.500 hectares para conservação da Mata Atlântica. Em uma entrevista concedida a Revista Ecológico, especialmente a respeito da RPPN Porto do Cajueiro, o diretor afirma que "não somos mais aqueles senhores de engenho" (REVISTA ECOLÓGICO, 2011, s/p). Tal afirmação se baseia nas atividades de "desenvolvimento sustentável" desenvolvidas pela empresa. Alguns trechos da entrevista ajudam-nos a compreender melhor o processo:

(Ao narrar a história da RPPN)

Temos um grande amigo, o Alberto Fonseca, que foi o primeiro Promotor de Justiça da Promotoria de Justiça Coletiva Especializada de Defesa do Meio Ambiente do MP de Alagoas. Foi ele que nos incentivou a formar a Reserva Particular do Patrimônio Natural (RPPN) Porto Cajueiro, em Januária (...).

(...) Empresário hoje que não tiver compromisso real com o desenvolvimento sustentável e a correlata preservação de ambientes naturais está fora do mercado. (...) Pensando e agindo como num passado insustentável, ele pode até sobreviver mais cinco, 10 anos no mercado. Mas um dia será

Estudos Geográficos, Rio Claro, 15(1): 184-209, jan/jun. 2017 (ISSN 1678—698X)

http://www.periodicos.rc.biblioteca.unesp.br/index.php/estgeo 
excluído, sairá da produção. A sociedade, a opinião pública, ninguém o perdoará. Isso é inexorável.

(...) Se não há mais como recuperarmos a natureza que existia no Triângulo, vamos compensar investindo e preservando o que ainda existe naturalmente em outras regiões do Estado (...). É. Mas somente para as empresas que, infelizmente, ainda pensam que isto é custo e não investimento a médio e longo prazo. Só para se ter uma ideia, nós talvez sejamos hoje, entre as 400 usinas de açúcar e álcool do Brasil, um dos poucos grupos que podem exportar etanol para a Inglaterra. Sabe por quê? Porque quando os empresários ingleses vêm aqui para comprar esse nosso combustível limpo, eles primeiro fazem uma auditoria ambiental e trabalhista, que é muito criteriosa.

Eles querem conhecer de perto o que estamos fazendo, querem visitar as reservas legais, tudo. Isso aconteceu recentemente com o pessoal do HSBC de Nova York e Rabobank da Holanda. Eles passaram dois dias na nossa RPPN para verificar se o que falávamos era verdade.

Ou seja, hoje o empresário só tira financiamento junto a um banco de primeira linha se ele tiver tudo em conformidade ambiental e trabalhista (...). O que poderíamos chamar custo, e foi mesmo na época, acabou virando lucro. Isso é real, é ecológico (REVISTA ECOLÓGICO, 2011, s/p).

Lucros, mercado e sustentabilidade são as palavras que resumem todo o conteúdo da entrevista citada. A sutileza da relação destes termos na entrevista configura um campo discursivo interessante para análise. Em perspectiva comparada, o entrevistado situa o modo como os empresários agiam no passado e como devem agir hoje para ter acesso a segmentos importantes do mercado, este modo de agir inclui indubitavelmente o "desenvolvimento sustentável". Este funciona como elo entre as demandas do mercado e, ao mesmo tempo, desejo da "sustentabilidade" materializada empírica e discursivamente na RPPN Porto do Cajueiro.

Nesse sentido, quando nos indagamos quais motivos levam empresas como a Usina Coruripe do Grupo Tércio Wanderley a criarem RPPN na região do mosaico, as respostas mais plausíveis são: (1) dada a degradação de áreas legalmente protegidas na região de atuação da usina, procurar outros lugares com o solo mais barato, com isenção de impostos é uma estratégia econômica; (2) a RPPN Porto do Cajueiro abre espaço para o reconhecimento da empresa como uma "empresa sustentável", o que permite captar novos nichos de negócios; (2) facilidade de créditos para expansão das atividades produtivas da empresa e créditos para gestão da RPPN também são elementos que atraem a empresa para a criação da reserva. Estas conclusões podem ser retiradas do trecho de entrevista citado anteriormente. Além disso, por mais que estas reservas sejam uma estratégia importante, é importante fazer algumas ponderações.

A primeira destas ponderações é a respeito das estratégias de conservação da biodiversidade, bem como as práticas de manejo nas RPPNs. É preciso considerar que isto fica a intento dos proprietários e estes, por sua vez, depois de averbada a área enquanto RPPN não têm obrigação jurídica de desenvolver qualquer atividade a este respeito. Aliada a isto, existe também a falta de fiscalização e acompanhamento do atendimento dos reais propósitos declarados no ato de criação, não tendo, portanto, nenhum mecanismo de controle de impactos Estudos Geográficos, Rio Claro, 15(1): 184-209, jan/jun. 2017 (ISSN 1678-698X) 
ambientais causados pelos usos da propriedade. E, por fim, o critério mais sensível de todos, não há garantia de que as RPPNs estejam em condições prioritárias de conservação e, menos ainda, a garantia da repartição dos benefícios da biodiversidade conservada.

Estas questões abrem espaço para um novo conjunto de reflexões. Em que condições estas RPPNs se integram ao manejo integrado e participativo do MSVP? Por fim, ao observar a historicidade das RPPNs, notamos o imbricamento de mais um conjunto de interesses e de agentes: PNUD, GEF e Grupo Tércio Wanderley e, sobretudo, a mediação constante da Funatura. Nesse sentido, a convergência destes sujeitos para a região do MSPV demonstra a espacialização de determinadas estratégias de conservação. Enquanto lugar destinado à conservação, fatores econômicos ajudam a materializar este fenômeno, sobretudo, o baixo preço do solo em relação a outras regiões.

\section{CONSIDERAÇÕES FINAIS}

Este artigo demonstrou como as Unidades de Conservação funcionam como mecanismo de modulação do espaço e, como tal, fazem parte de uma estratégia política de controle e interdição dos territórios e de seus recursos. O principal recurso dos territórios apropriados pelas UCs é a biodiversidade. Nesse sentido, as UCs se tornam fundos territoriais, reservas estratégicas do Estado brasileiro.

Ao focarmos empiricamente as UCs que compõem o MSVP, lançamos mão de um olhar histórico que nos permitiu observar dois pontos de rupturas complementares e distintos entre si. Ressaltamos a expansão de projetos econômicos baseados no discurso ideológico da ocupação dos "vazios" territoriais a partir da década de 1970, baseados na lógica de expropriação e degradação da natureza. Tais projetos econômicos traçam uma marca na paisagem, modificam as relações sociais e criam dinâmicas outrora inexistentes. Em suma: subjaz a esses, uma lógica distinta de relação sociedade-natureza pautada pela negatividade, na qual a natureza é vista como mero estoque de recursos ou como elemento que explicava o atraso regional. Esta negatividade da natureza teve consequências empíricas importantes, de cunho ambiental (perda de biodiversidade, degradação do Cerrado e assoreamentos de veredas e rios, etc.) e também social (expropriação de territórios das comunidades camponesas, conflitos.).

A partir de 1980, uma nova formação discursiva ganha forma, sobretudo, pela atuação de movimentos ambientalistas e cientistas: a positivação da natureza. A partir disso, os elementos bióticos e abióticos foram vistos positivamente. Um movimento antitético, a lógica espoliativa pretérita que desemboca na criação das UCs. As UCs surgem como mecanismos territoriais, haja vista que ocupam um território determinado, modulando-o técnica e normativamente. Em outras palavras, a conservação ambiental via delimitação de espaços específicos para tal fim é iminentemente territorial, mas também político e normativo. À medida que as UCs se consolidam, conjuntamente, se consolida um conjunto de interesses, interessados, conflitos, regras e normas de uso da natureza, todos se desdobram em um projeto de natureza a ser conservada.

Os eventos descritos mostram a simultaneidade de duas lógicas espaciais distintas, de duas lógicas de uso e apropriação da natureza, mas é preciso considerar que o espaço geográfico sobre o qual incidem estes eventos tinha uma história. Aquela das populações camponesas que ocupam as Veredas, Encostas,

Estudos Geográficos, Rio Claro, 15(1): 184-209, jan/jun. 2017 (ISSN 1678-698X)

http://www.periodicos.rc.biblioteca.unesp.br/index.php/estgeo 
Chapadas, Resfriados, enfim, o Cerrado em sua multiplicidade. Estas populações têm uma lógica distinta de se relacionar com a natureza ao apropriar-se dela simbólica e materialmente, dando origem àquilo que denominamos de socionatureza: quando elementos naturais e sociais se fundem formando objetos híbridos.

Enquanto mecanismo político de modulação do espaço, as UCs dispõem as atividades produtivas e os homens, segundo uma lógica, e como tal, dita os usos e não usos possíveis para o lugar de sua materialização. Aliás, este é o sentido mais claro do efeito político das UCs: a produção de diferenças espaciais segundo uma lógica de gestão e ordenamento do espaço. Isto, evidentemente, gera uma escala múltipla de conflitos. É preciso destacar, como argumentamos neste texto, que o que está em jogo é o controle do território e, consequentemente, dos seus recursos genéticos, mineiras, águas e solos. Estes conflitos podem ser de escala local, mas conforme se expande a territorialização da conservação, ganha também concretude em outras escalas como a regional, a exemplo da região a Norte de Minas Gerais.

\section{REFERÊNCIAS}

ABDALA, Fábio de Andrade. O poder da floresta: ecologia e política internacional na Amazônia. 2000. 198 f. Dissertação (Mestrado em Ciências Políticas)-IFCH/ Unicamp, Campinas, 2000.

ACSELRAD, Henri. Externalidade ambiental e sociabilidade capitalista. In: CAVALCANTI, Clóvis (org.). Desenvolvimento e natureza: estudos para uma sociedade sustentável. São Paulo: Cortez, 1995. p.128-138.

AYALA, Luci. Empresas aliadas da natureza: as reservas particulares como estratégia ambiental corporativa. Brasília/São Paulo: SOS Mata Atlântica e The Nature Conservancy, 2010.

BAGGIO FILHO, Hernando. O município de Buritizeiro e a questão do pinus e do eucalipto: implicações de seu plantio homogêneo generalizado no meio ambiente físico, biológico e socioeconômico. In: RODRIGUES, Luciene; MAIA, Cláudia (org.). Cerrado em perspectiva(s). Montes Claros: Unimontes, 2003. p.27-90.

BARBOSA, Rômulo Soares; SANTOS, Fábio Dias dos. Unidades de proteção integral como compensação ambiental ao Projeto Jaíba, no Norte de Minas Gerais: mobilização e resistência das populações locais. Revista Cerrados, Montes Claros, v. 6, n.1, p. 11-32, 2008.

\section{BECHARA, Erika. Licenciamento e compensação ambiental na lei do Sistema Nacional das Unidades de Conservação (SNUC). São Paulo: Editora Atlas S. A, 2009.}

BECKER, Bertha K. Repensando a questão ambiental no Brasil a partir da geopolítica. In: Leal, Maria do Carmo; SABROZA, Paulo Chagastelles; RODRIGUES, Rodolfo Hector; BUSS, Paulo Marchiori (org.). Saúde, ambiente e desenvolvimento: uma análise interdisciplinar. Vol. 1. São Paulo: Hucitec, 1992. p. 127-152. 
BERNARDES, Aline Tristão. Establishment of private natural heritage reserves (RPPNS) in the brazilian Cerrado. Brasília: Relatório Final, 2006.

BETHONICO, Maria Bárbara de Magalhães. Área de Proteção Ambiental Estadual do rio Pandeiros - MG: espaço, território e atores. 2009. 290 f. Tese (Doutorado em Geografia)-PPGEO/UFF, Niterói-RJ, 2009.

BRASIL. Sistema nacional de unidades de conservação da Natureza - SNUC. Lei 9985 de 18 de julho de 2000; Decreto no 4340 de 22 de agosto de 2002. Ed. Aumentada. Brasília: MMAISBF, 2000.

CASTRO JÚNIOR, Evaristo de; COUTINHO, Bruno Henrique; FREITAS, Leandro Esteves de. Gestão da biodiversidade e áreas protegidas. In: GUERRA, Antonio José Teixeira; COELHO, Maria Célia Nunes (org.). Unidades de Conservação: abordagens e características geográficas. Bertrand Brasil: Rio de Janeiro, 2009. p. 25-65.

DIEGUES, Antonio Carlos. (Org.) A ecologia política das grandes ONGs transnacionais da conservação. São Paulo: Núcleo de Apoio à Pesquisa sobre Populações Humanas e Áreas Úmidas Brasileiras-NUPAUB/USP, 2008.

DUPAS, Gilberto. Mito do progresso ou progresso como ideologia. São2006 Paulo: Editora da UNESP, 2006.

GERVAISE, Yves. A transformação agrária do nordeste meridional (Norte de Minas). Publicação especial 1. Belo Horizonte: Departamento de Geografia/UFMG, 1975.

GONZAGA, Carlos M. A. Economia e meio ambiente: trópicos introdutórios. Santa Cruz/Paraná: UNICENTRO, 2013.

GOVERNO DE MINAS GERAIS. Condicionantes ambientais: PE-25, Projeto Jaíba. Governo do Estado de Minas Gerais, 2006.

IBAMA/MMA. Instrução Normativa no 9, de 24 de Outubro de 2003. Estabelece critérios e procedimentos administrativos para a regularização fundiária de unidades de conservação federais. IBAMA/MMA, 2003.

MINAS GERAIS. Lei no 9.375, de 12 de Dezembro de 1986. Declara Interesse comum e de preservação permanente os ecossistemas das veredas no Estado de Minas Gerais. Minas Gerais, 1986.

MUNGAI, Mariana França. Mosaico de interesses, representações e conflitos: o Parque Nacional Cavernas Do Peruaçu - MG. 2008. 201 f. Dissertação (Mestrado em Geografia) - PPGEO/UFMG, Belo Horizonte, 2008.

OLIVEIRA, Valeska Buchemi de; PAGLIA, Adriano Pereira; FONSECA, Mônica; GUIMARÃES, Erika. Mata Atlântica-RPPN e biodiversidade: o papel das Reservas Particulares na Proteção da biodiversidade da Mata Atlântica. Belo Horizonte: 
Conservação Internacional; São Paulo: Fundação SOS Mata Atlântica; Curitiba: The Nature Conservancy, 2010.

PROGRAMA DAS NAÇÕES UNIDAS PARA O DESENVOLVIMENTO - PNUD. Cerrado ganha 13 reservas particulares. Reportagem de 04 de Março de 2004. Disponível em: <<http://www.pnud.org.br/Noticia.aspx?id=3

RICUPERO, Bernardo; ABDALA, Fábio de Andrade; MARIANO, Karina L. Pasquariello. Meio ambiente e dívida externa: anotações de uma pesquisa. Cadernos CEDEC, São Paulo, №. 40, p.1-36, 1995.

RODRIGUES, Luciene. A formação econômica do norte de minas e o período recente. In: RODRIGUES, Luciene; OLIVEIRA, Marcos Fábio Martins de (org.). Formação econômica e social do norte de minas. Montes Claros: UNIMONTES, 2000. p. 105170.

SATHLER, Evandro Bastos. Os "espaços de incerteza", a "desterritorialização subjetiva" e o "pacto da conservação": perspectivas de uma geografia socioambiental das áreas naturais protegidas. 2010. $334 \mathrm{f}$. Tese (Doutorado em Geografia)- PPG em Geografia, UFF, Niterói-RJ, 2010.

SILVA, Carlos Eduardo Mazzeto. O cerrado em disputa: apropriação global e resistências locais. Brasília: Confea, 2009.

SEMAD. Licenciamento. Disponível em:

<<http://www.semad.mg.gov.br/regularizacao-ambiental/licenciamento >>. Acesso em: fev. 2013.

SENNES, Ricardo Ubiraci. A conversão da dívida externa em investimentos.

Cadernos CEDEC, São Paulo, №. 29, p.1-25, 1993.

TC-Termo de Compromisso. MMA e FIAT Automóveis S/A. PAC/ MPF - Procedimento Administrativo cível/ Ministério Público Federal - Procedimento Administrativo Cível MPF/PGR - №. 08112.000968/94-41 que trata do auto de infração aplicada à FIAT Automóveis S/A no dia 21 de Dezembro de 1995. MPF, 1997.

WALDMAN, Márcio. Oito Críticas Ecológicas à Conversão da Dívida. In SCHILLING, Paulo R.; CRUZ, Paulo D. C. Conversão da Dívida e Meio Ambiente. São Paulo: CEDI/GRAAL, 1992. p. 59-82(1-21).

WANDERLEY JUNIOR, Vitor Montenegro . Não somos mais aqueles senhores de engenho. Revista Ecológico, n 32, s/p, 2011. Disponível em <<:

http://mww.revistaecologico.com.br/materia.php?id=32\&secao=405\&mat=415 >>. Acesso em 23 de fev. de 2013. 